\title{
The chironomid (Diptera) communities in two sediment cores from Store Hovvatn, S. Norway, an acidified lake
}

\author{
$\emptyset . A$. Schnell ${ }^{1}$ \\ E. Willassen ${ }^{1}$
}

Keywords : Chironomidae, palaeolimnology, acidification, ecotoxicology.

Two sediment cores from acid lake Store Hovvatn were ánalysed for chironomid head capsule remains over a sequence spanning from about 1730 A.D. to the late 1970s. Up to 30 taxa were identified from one $(0.5 \mathrm{~cm})$ level in the cores. Principal component analysis of taxon relative abundances showed a gradient corresponding more or less to the sediment sample chronology. Redundancy analysis with some chemostratigraphical variables, and with $\mathrm{pH}$ values inferred from diatoms, indicated that chironomid community change could be explained as a response to acidification. However, most of the taxa that declined or disappeared up-core are known to occur in acid lakes and $\mathrm{pH}$ sensitivity per se does not seem to explain the response of individual species. The relative abundance of Orthocladiinae increased up-core and the long term change may be conceived in terms of a retarded productivity or oligotrophication. The most conspicuous change in the chironomid community appears to coincide with decreasing aluminium concentrations in the sediments and may indicate toxic effects from labile aluminium in the water column.

Les communautés chironomidiennes (Diptera) dans, deux carottes de sédiments du lac acide Store Hovvatn (S. Norvège)

Mots clés : Chironomidae, paléolimnologie, acidification, écotoxicologie.

Deux carottes de sédiments du lac acide Store Hovvatn ont été analysées à partir des restes de capsules céphaliques de Chironomidés sur une durée allant d'environ 1730 à la fin des années 1970. Jusqu'à 30 taxa ont été identifiés, dans un sẹul niveau $(0,5 \mathrm{~cm})$ de la carotte. Une Analyse en Composantes Principales de l'abondance relative des taxons a montré un gradient qui correspond sensiblement à la chronologie de la carotte.

Une analyse de redondance avec quelques variables chimiostratigraphiques et avec des valeurs de ph reconstituées à partir des diatomées indiquait que les changements de la communauté chironomidienne pourraient s'expliquer comme une réponse à l'acidification. Cependant, la majorité des taxa qui ont diminué ou disparu dans la partie haute de la carotte sont réputés vivre dans les lacs acides et la sensibilité au pH en elle-même ne paraît pas expliquer la réponse individuelle des espèces. L'abondance relative des Orthocladiinae augmente dans le haut de la carotte et le changement à long terme peut être interprété comme une régression de la productivité ou une oligotrophisation. Le changement le plus net de la communauté chironomidienne paraît correspondre avec les concentrations décroissantes en aluminium dans les sédiments et peut être l'indice d'effets toxiques de l'aluminium libre dans la colonne d'eau.

\section{Introduction}

The detrimental effects of acid precipitation on natural ecosystems have received much attention during the last 20 years and several studies have previously focused on its effects on lacustrine chironomid com-

1. Institute of Zoology, University of Bergen, Muséplass 3, N-5007 Bergen, Norway. munities (Mossberg 1979, Mossberg \& Nyberg 1976, 1979, Raddum \& Sæather 1981, Wiederholm \& Erikson 1977, Walker et al. 1985). The lake Store Hovvatn (Fig.1) has a central position in the history of Norwegian acidification studies. It was included in the «SNSF»-project («Acid precipitation - effects on forest and fish») (Drabløs \& Tollan 1980) and was, therefore, extensively investigated. Davis et al. (1985), using diatoms, inferred that the $\mathrm{pH}$ of Store Hovvatn had been fluctuating around 4.9-5.2 for many centuries, prior to its decline beginning in the 1800 s. Measured $\mathrm{pH}$ values reached approximately 4.4-4.6 in 1978. A population of brown trout (Salmo trutta (L.)) 


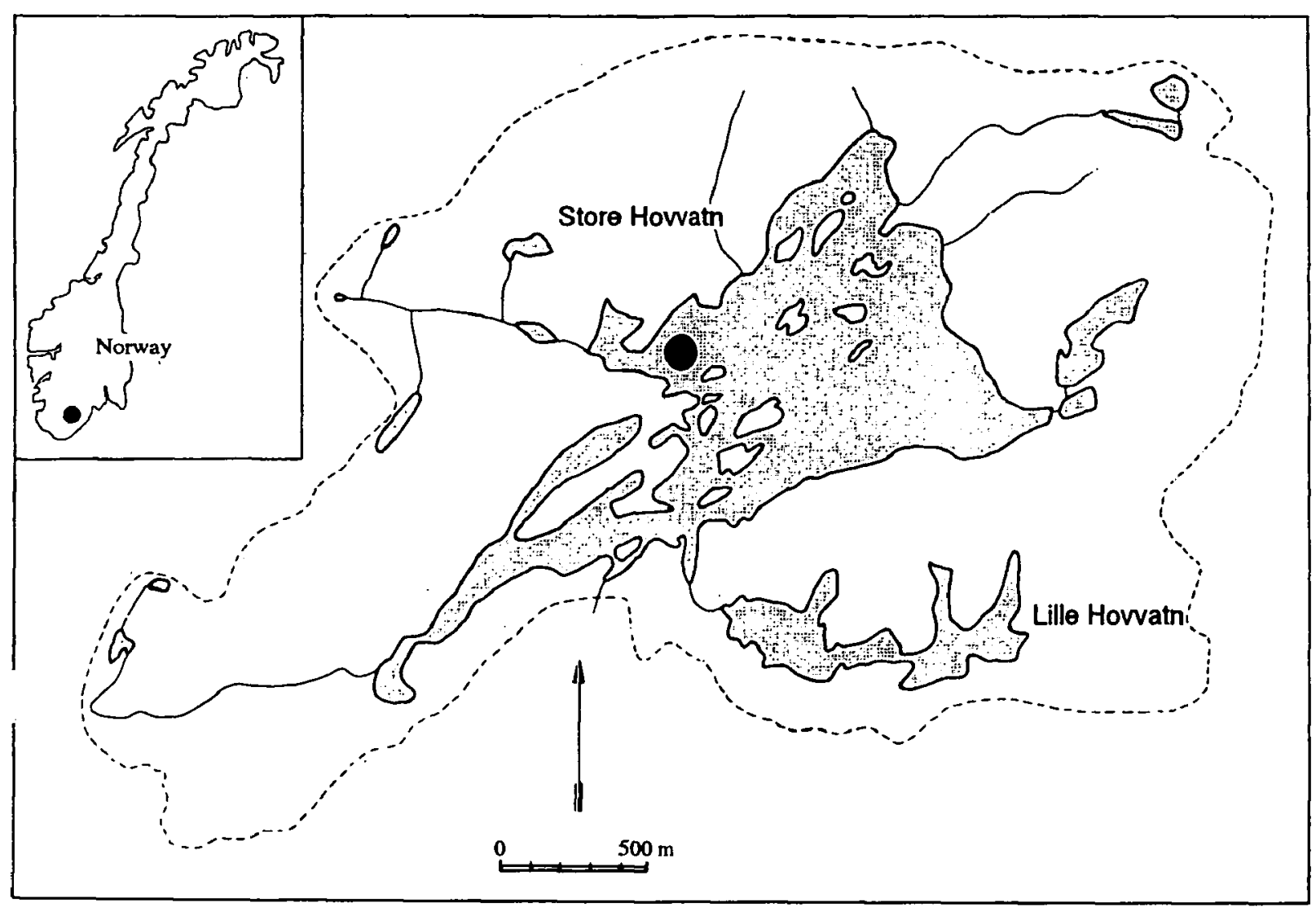

Fig.1 . Map of Store Hovvatn with coring sites (dot), Lille Hovvatn, and the catchment basin of the lakes (stippled). (Modified from Raddum et al. 1986).

Fig. 1. Carte des lacs Store Hovvatn, avec station de carottage (point), Lille Hovvatn, et tracé de leur bassin versant (modifié de Raddum et al. 1986).

had become extinct by the 1930s (B. Barlaup, University of Bergen, pers.comm.). The lake was regarded as chronically acidified when it was selected as one of the main sites for the «Liming Project» (Baalsrud 1985). The lake was extensively limed in 1981, and then relimed in 1987, 1989 and 1991. Research activities continue at Store Hovvatn to investigate effects of acid deposition and liming on water chemistry and aquatic organisms. Previous studies of Store Hovvatn include research by Wright (1985) and Hindar (1987) on water chemistry, Raddum et al. (1986) on chemistry and biology in general, and Barlaup et al. $(1989,1994)$ on fish biology.

Chironomid midges are highly regarded as indicators of environmental change (Walker 1995). Direct records of community change can be found in sediment profiles, and some authors (Henrikson \& Oscarson 1985, Hultberg 1985, Johnson \& McNeill 1988, Brodin 1990) have previously submitted historical evidence of acidification based on stratigraphical studies of chironomid head capsules.

In this paper, we report the results from an analysis of chironomid head capsule remains found in two sediment cores retrieved from Store Hovvatn before the lake chemistry was manipulated with lime. One of these cores has previously been analysed for chemical stratigraphy (Norton \& Hess 1980), diatoms (Davis \& Berge 1980, Davis et al. 1985) and cladoceran remains (Brakke 1980). The data derived from these studies provide an excellent opportunity to interpret chironomid community changes from the perspective of known abiotic and biotic factors.

When interpreting chironomid species tolerances to acidification, we shall also use additional evidence from bottom samples taken in Store Hovvatn and from another lake, Lille Hovvatn, which is connected via influx to Store Hovvatn through a ca. $100 \mathrm{~m}$ long brook.

\section{Site description}

Store Hovvatn (Fig.1) has a surface area of $1.1 \mathrm{~km}^{2}$. It is situated at $494 \mathrm{~m}$ a.s.l. in southernmost Norway (58 37' N $8^{\circ} 2^{\prime}$ E, UTM 32VMK440975). The area is strongly affected by acid deposition (Anonymous 1987). The surroundings are mostly bare bedrock and bogs, with sparse pine, spruce, and birch forest interspersed. The lake is situated in a bedrock depression, which suggests that the water-level may have been the 
same or slightly higher since deglaciation. There is no large inlet river, only a few minor tributaries, and most of the water drains into the lake through seepage from bogs. The catchment has an area of $5.8 \mathrm{~km}^{2}$.

Lille Hovvatn is situated at $504 \mathrm{~m}$ a.s.l. and drains into Store Hovvatn via a ca. $100 \mathrm{~m}$ long brook. This lake is being used as an untreated reference lake to compare with Store Hovvatn following chemical manipulations. It is devoid of fish, has $\mathrm{pH}$ values between 4.3 and 4.6 (Hindar 1987), and the present water chemistry is very similar to that of Store Hovvatn before liming (Wright 1985).

\section{Material and methods}

\subsection{The cores}

Two sediment cores, designated $4.1 \mathrm{~A}$ and $4.1 \mathrm{~B}$, were taken in close proximity, at $10 \mathrm{~m}$ water depth in the western part of Store Hovvatn, March 1978. The sampler used was a stationary-piston corer with a tube diameter of $6.4 \mathrm{~cm}$ (Norton \& Hess 1980). The top 30 centimetres of the cores were sectioned into $0.5 \mathrm{~cm}$ thick samples, while the remaining sediment column was sectioned into $1 \mathrm{~cm}$ thick slices. Both cores were sectioned within one day after retrieval and the samples were temporarily stored in plastic bags at low temperature $\left(5^{\circ} \mathrm{C}\right)$ until being processed. Core $4.1 \mathrm{~A}$ was sorted and the chironomid remains mounted shortly after retrieval, while 4.1B was sorted and analysed in 1994.

The two cores were treated differently with respect to analysis of chironomid remains. Each sample from core $4.1 \mathrm{~A}$ was obtained by amalgamating sediments from adjacent pairs of $0.5 \mathrm{~cm}$ slices and by subsequently subsampling three $\mathrm{ml}$ of wet sediment for analysis. The samples were treated with $\mathrm{KOH}$-solution and sieved prior to sorting, following the procedure outlined by Warwick (1980) ( R.B. Davis, pers. comm.). After deflocculation in $\mathrm{KOH}$, the chironomid remains were picked out under a stereo microscope, and all specimens were mounted on microscope slides in Euparal for identification.

Core $4.1 \mathrm{~B}$ was analysed by picking head capsule remains directly from the $0.5 \mathrm{~cm}$ slices of untreated sediments under a stereo microscope. This procedure was chosen in order to preserve structures that very easily break apart from the head capsules under treatment with $\mathrm{KOH}$, especially the mandible and labrum. These structures are important for identification of chironomid species. The head capsules were then stored in $70 \%$ ethanol, and some specimens were mounted in Hoyer $\mathbf{s}$ solution on microscope slides. A certain portion of easily recognisable species could be identified under the stereo microscope and only single specimens were mounted in Hoyer's solution in order to confirm the identification under higher magnification.

Head capsules from untreated samples retain, to a much greater extent, the taxonomically important structures. Thus, a larger proportion of the sample can be identified to species level. This is particularly true for Tanypodinae and Tanytarsini. On the other hand, direct sorting from fresh sediments yields fewer head capsules because the samples are not deflocculated in $\mathrm{KOH}$, and larger volumes of sediment must be sorted. Also, sorting is in general more difficult and tiresome with fresh sediments. However, either way, the sorting procedure is very time consuming.

Identifications of chironomid taxa were based on diagnoses to genera in Wiederholm (1983) plus a wide range of taxonomic literature.

Chironomid head capsules that included the complete mentum were counted as one head capsule. Split fragments of head capsules that included half the mentum were common among Orthocladiinae. These fragments were counted as halves.

\subsection{Dating and chemical stratigraphy}

Core 4.1A was originally dated with ${ }^{137} \mathrm{Cs}$ (Norton \& Hess 1980). However, in this study we use datings subsequently obtained with ${ }^{210} \mathrm{~Pb}$ (Davis et al. 1985), which tended to yield much older ages. In the analysis of relationships between chironomid communities and the chemical stratigraphy of core 4.1 A, we used data provided by Norton \& Hess (1980). The $\mathrm{pH}$ for each level in the core was scored from the profiles inferred by Davis et al. (1985). Since Davis et al. (1985 : fig. 1) obtained slightly diverging reconstructions from regressions of diatom groups and from regressions based on principal component analysis, we used approximate means of the $\mathrm{pH}$ values obtained from these two methods. Core 4.1B was neither dated nor analysed for chemical stratigraphy.

\subsection{Modern chironomid community reference samples}

The composition of the Store Hovvatn benthic fauna, before the first chemical manipulation with lime, was assessed from samples of larvae taken in the autumn of 1977 and in spring 1978. Between 22 and 30 samples were retrieved with a Kajak sampler from each of four depth levels : $0.5 \mathrm{~m}, 2 \mathrm{~m}, 5 \mathrm{~m}$, and $10 \mathrm{~m}$. This sampling programme has been conducted more or less continuously to the present day. Lille Hovvatn was included in a similar sampling scheme in 1988. The chironomid larvae from these samples were identified for comparison with the sediment cores. 


\subsection{Data analyses}

Species diversity was calculated from abundances with the Shannon-Weaver index. Relative abundance of species (\%) was calculated for each sample and further numerical analyses were based on percentage data.

The computer programs TILIA and TILIA-Graph (E.Grimm, Illinois State Museum, Springfield, IL, USA) were used to produce stratigraphic diagrams and to calculate stratigraphically constrained clusters of the samples from the species data. The cluster analyses were based on between-sample-Cavalli-Sforzadistances.

Other statistical analyses of the core data were done with the software package Canoco 3.10 (ter Braak 1987-1992). Principal component analysis (PCA), and redundancy analyses (RDA) were performed on species matrices excluding those taxa that did not exceed $2 \%$ abundance in any strata of the core. The chironomid percentages were transformed to square roots prior to numerical analyses.

In order to find possible relationships between the species composition and a selection of other sediment characteristics, environmental variables were scored from previously published sources. Values for four of these variables (lead, aluminium, zinc and organic content) were based on measurement from core 4.1A (Norton \& Hess 1980). Values for total organic content (TOC) and $\mathrm{pH}$ in the lake were based on the profiles inferred by Davis et al. (1985).

Unrestricted Monte Carlo tests with 999 permutations were used in RDA to test the significance of the ordination, and the significance of the first axis. The significance of the second axis was tested similarly by subsequently utilising the RDA-solution as a covariable-file in a second run with RDA. Monte Carlo testing was also used in partial, constrained RDA to test the significance of the stratigraphical environmental variables.

\section{Results}

\subsection{Core 4.1A}

Eight samples from the upper $17 \mathrm{~cm}$ were analysed from core 4.1A (Table 1). A total of 646 chironomid head capsules were found. The relative abundances of the taxa are shown in Fig.2. The most important taxa were Heterotrissocladius brundini Saether \& Schnell, Heterotanytarsus apicalis (Kieffer), Heterotrissocladius marcidus (Walker), Microtendipes cf. pedellus (De Geer), Heterotrissocladius grimshawi (Edwards), Ablabesmyia monilis (L.), and Sergentia coracina (Zetterstedt). These taxa made up $66 \%$ of the specimens found in core 4.1 A. H. brundini was the dominant species in all samples except between $0-1 \mathrm{~cm}$, where $H$. marcidus dominated. $M$. cf. pedellus showed the most pronounced decrease in abundance up-core, from $22 \%$ in the sample at $16-17 \mathrm{~cm}$ to no specimens in the two top samples. S. coracina also decreased, and was not found in the samples from $2-3$ and $1-0 \mathrm{~cm}$. $H$. marcidus increased from about $4 \%$ of the total in the bottom sample to about $28 \%$ in the top sample at $0-1$ $\mathrm{cm}$. $H$. apicalis showed the same tendency, with just over $1 \%$ in the bottom sample to $10 \%$ at the top.

Based on the results from the cluster analysis, we recognized four stratigraphic zones in core 4.1A (Fig.2). Zone $\mathrm{HAl}$ can be characterized by a relative increase in Heterotrissocladius spp. and a decline in several Tanypodinae and Chironominae species. A decrease in the number of taxa and in the influx rate of head cap-

Table 1. Numbers of head capsules (HC), head capsule concentration, species diversity, and relative abundance of chironomid subfamilies and tribes in core 4.1.A.

Tableau I. Nombres et concentration par volume des capsules céphaliques (HC), diversité spécifique et abondance relative des sous-familles et tribus de Chironomidés dans la carotte 4.1 A.

\begin{tabular}{|c|c|c|c|c|c|c|c|c|}
\hline Depth $(\mathrm{cm})$ & $16-17$ & $12-13$ & $10-11$ & $8-9$ & $6-7$ & $4-5$ & $2-3$ & $0-1$ \\
\hline No.HC & 81 & 58 & 149 & 87 & 86 & 107 & 20 & 58 \\
\hline $\mathrm{HC} \mathrm{ml-1}$ & 27 & 19 & 50 & 29 & 29 & 36 & 7 & 19 \\
\hline Species diversity & 2.5 & 2.0 & 2.6 & 2.6 & 2.7 & 3.2 & 1.7 & 2.2 \\
\hline \multicolumn{9}{|l|}{ Rel. abundance (\%) } \\
\hline Tanypodinae & 10 & 3 & 11 & 15 & 9 & 4 & 0 & 3 \\
\hline Orthocladiinae & 43 & 66 & 58 & 51 & 53 & 66 & 85 & 78 \\
\hline Chironomini & 37 & 12 & 17 & 20 & 12 & 13 & 10 & 12 \\
\hline Pseudochironomini & 0 & 0 & 2 & 2 & 1 & 2 & 0 & 0 \\
\hline Tanytarsini & 10 & 19 & 10 & 13 & 24 & 14 & 5 & 5 \\
\hline
\end{tabular}




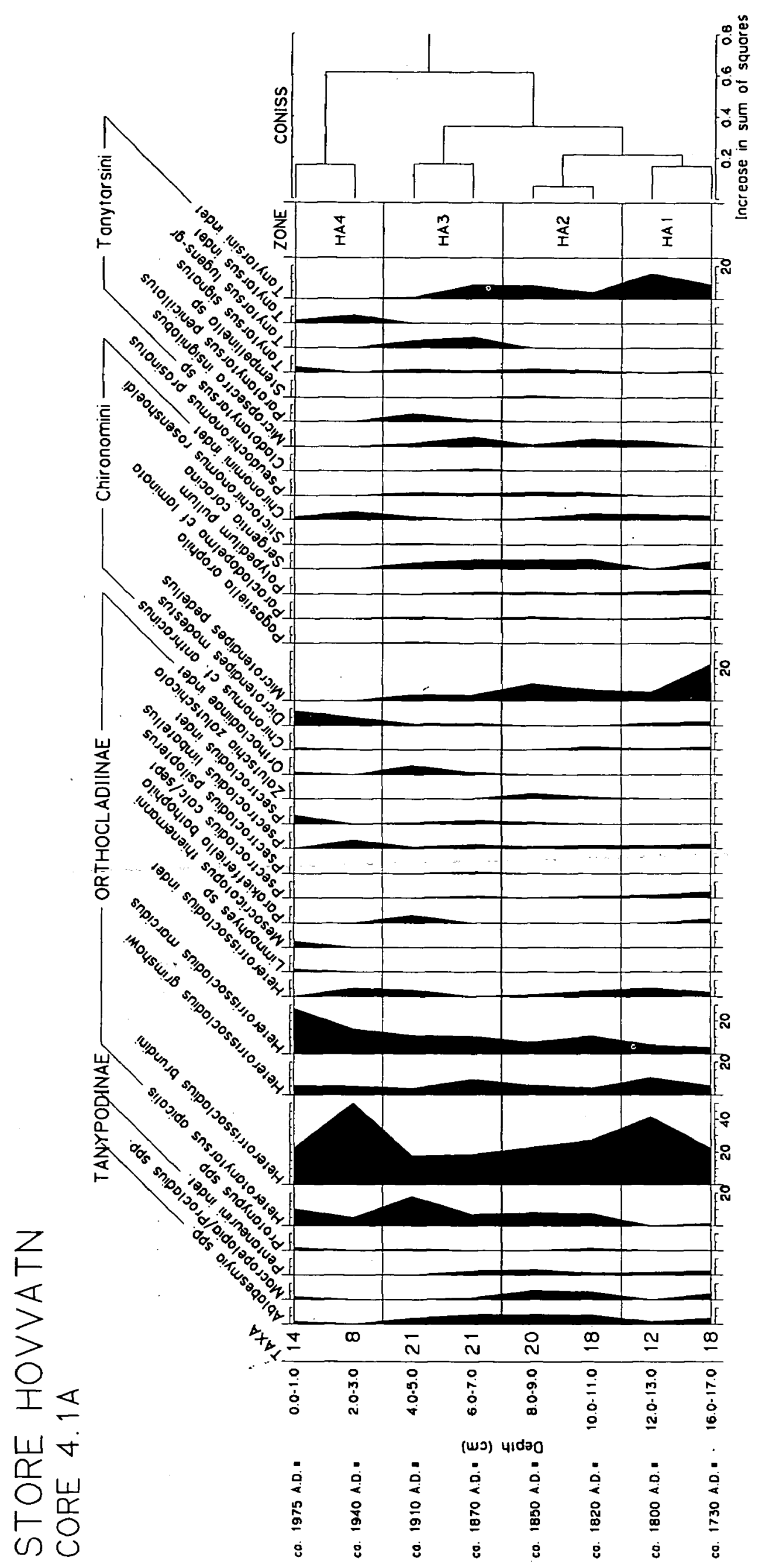


sules was also apparent in this segment of the core. The particular tendency of the change in species composition in zone HA1 is partly reversed in zone HA2. With $H$. brundini declining, and tanypods and some Chironominae including Sergentia reappearing. The number of taxa is restored in the transition between zones HA1 and HA2.

Zone HA3 shows a new decline of tanypods, increasing Heterotrissocladius, and a peak in H. apicalis and the Tanytarsus lugens group. This zone also displays the occurrence of some of the more ephemeral species in the core.

Inferred from the cluster analysis, the most important change in species composition appears in the transition to zone HA4 where there is a conspicuous peak in the relative abundance of $H$. brundini while most species of Chironomini and Tanytarsini disappear. Concurrently, the concentration of head capsules is at a minimum (Table 1) and the number of recorded species is down to eight. However, a few Tanypodinae and Chironominae reappear in the upper part of this zone, whereas there is tendency of $H$. marcidus to replace H.brundini as the dominant taxon.

\subsection{Core 4.1B}

A total of 10 samples were sorted and analysed upcore from the 16-16.5 cm level (Table 2, Fig.3) and 706 head capsules were recovered. Core $4.1 \mathrm{~A}$ displays very much the same patterns of fluctuating change in species composition as in core 4.1A. The four main zones emerging from the cluster analysis are not fully correspondent with those from core 4.1A.

In terms of relative species composition, zone HB1 indicates a slight increase in $H$. brundini and a weak decrease in Ablabesmyia sp. and M. pedellus. These changes are more accentuated in the lower part of zone HB2 (Fig.3, dashed line). Thus, H. brundini has a maximum at $10-10.5 \mathrm{~cm}$, a level which more likely corresponds to the maximum at $12-13 \mathrm{~cm}$ in core $4.1 \mathrm{~A}$. At $8-8.5 \mathrm{~cm}$, head capsule concentration increases conspicuously and the number of species reaches a maximum. Apparently, this corresponds to a similar event at $10-11 \mathrm{~cm}$ in core $4.1 \mathrm{~A}$.

The transition from zone HB2 to HB3 marks the main cluster division in core $4.1 \mathrm{~B}$ with respect to species composition. The change is associated with either decline or reappearance of several otherwise sparsely represented species such as Parakiefferiella bathophila. Sergentia is replacing Microtendipes as the dominant Chironominae. There is also a slight increase in H.brundini. In the top section of zone HB3, H. apicalis has a peak in relative abundance which apparently corresponds to the peak at the $4-5 \mathrm{~cm}$ level in core $4.1 \mathrm{~A}$. Simultaneously, the head capsule concentration and species diversity (Table 2) drop to minimum values for the core.

The community change seen in zone HA4 is to a lar: ge extent reproduced in zone HB4. The peak in pro;portion of $H . b r u n d i n i$ at $2-3 \mathrm{~cm}$ is replaced by $H$.mar: cidus closer to the surface sediments and there is: a twofold increase in the number of species from $2 \mathrm{~cm}$ depth to the surface.

\subsection{Comparison of the cores}

The same species dominated in both cores: Some species were found in one core only. Mesocricotopus: thienemanni (Goetghebuer), Pagastiella orophila (Edwards), and Stempellinella sp: were found onlyy in core 4.1A, while Cricotopus (Cricotopus) sp., Georthocladius luteicornis (Goetghebuer), Psectrocladius. (Me-

Table 2. Numbers of head capsules, head capsule concentration, species diversity, and relative abundance of chironomid subfamilies; and tribes in core 4.1.B.

Tableau 2. Nombres et concentration par volume des capsules céphaliques (HC), diversité spécifique: et abondance relative des sous-familles et tribus de Chironomidés dans la carotte 4.1 B.

\begin{tabular}{lcccccccccc}
\hline Depth (cm) & 16.5 & 12.5 & 10.5 & 8.5 & 6.5 & 4.5 & 3.5 & 2.5 & 1.5 & 0.5 \\
\hline No.HC & 64 & 64 & 56 & 202 & 50 & 4 l & 14 & 27 & 72 \\
HC ml-1 & 4.0 & 4.0 & 3.5 & 12.6 & 3.1 & 2.5 & 1.7 & 3.4 & 9.0 & 7.2 \\
Species diversity & 2.1 & 2.3 & 1.8 & 2.9 & 2.5 & 2.4 & 2.0 & 1.7 & 1.8 & 2.3 \\
Rel. abundance (\%): & & & & & & & & \\
Tanypodinae & 33 & 13 & 7 & 20 & 14 & 27 & 14 & 15 & 8 \\
Orthocladiinae & 20 & 33 & 73 & 41 & 46 & 41 & 57 & 74 & 76 & 68 \\
Chironomini & 44 & 44 & 11 & 24 & 28 & 22 & 7 & 11 & 11 \\
Pseudochironomini & 0 & 0 & 4 & 1 & 2 & 0 & 7 & 0 & 0 \\
Tanytarsini & 2 & 9 & 5 & 11 & 10 & 5 & 7 & 0 & 0 \\
\hline
\end{tabular}




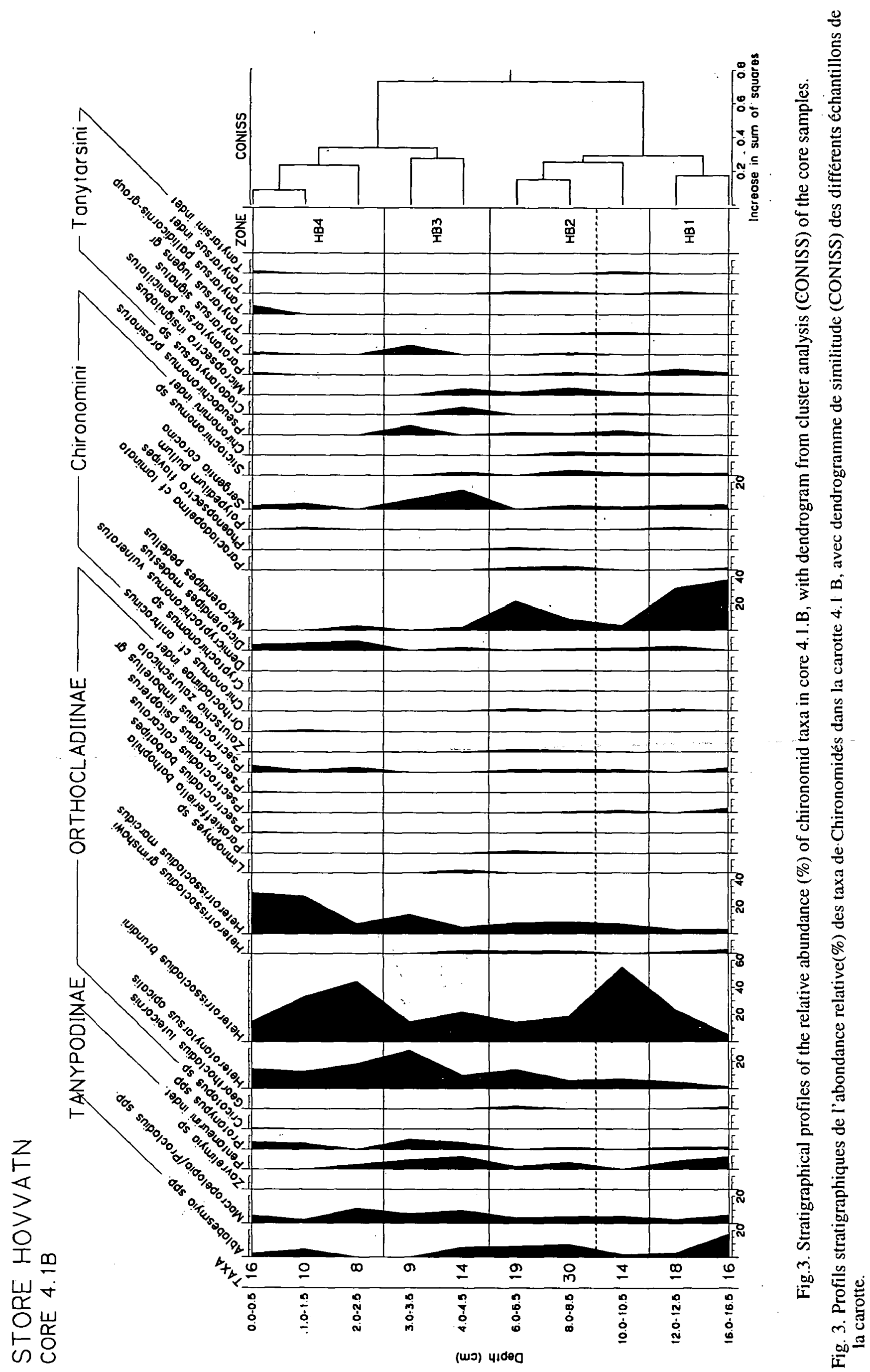


sopsectrocladius) barbatipes Kieffer, Cryptochironomus sp., Demicryptochironomus vulneratus (Zetterstedt), Stenochironomus sp., and Tanytarsus pallidicornis-group were found only in core 4.1B. However, none of these species were represented by more than a few specimens.

For further comparison we pooled the species data from both cores into one data set. Ordination with species-centered PCA (Fig.4) indicated a close correspondence between the first axis and the chronological sequence of the sediment samples. The second axis yielded a separation of the A- and B-samples that probably reflects the different sorting methods applied on the two cores.
Core 4.1 A was processed according to the recommended procedures for chironomid subfossil analyses (Warwick 1980, Hofmann 1986, Walker 1987) and yielded more specimens per sorted volume than core 4.1B which was not deflocculated with $\mathrm{KOH}$ prior to sorting. It is clearly much easier to overlook specimens in untreated samples. This is certainly a problem if inference is based on comparisons of quantitative data between cores. On the other hand, untreated samples yield better taxonomic resolution because important structures are retained.

The chronological sequence of the samples along the first axis is less perfect between 6 and $10 \mathrm{~cm}$. However, the top and bottom segments of the cores indicate a strong correlation between the sample scores for cores

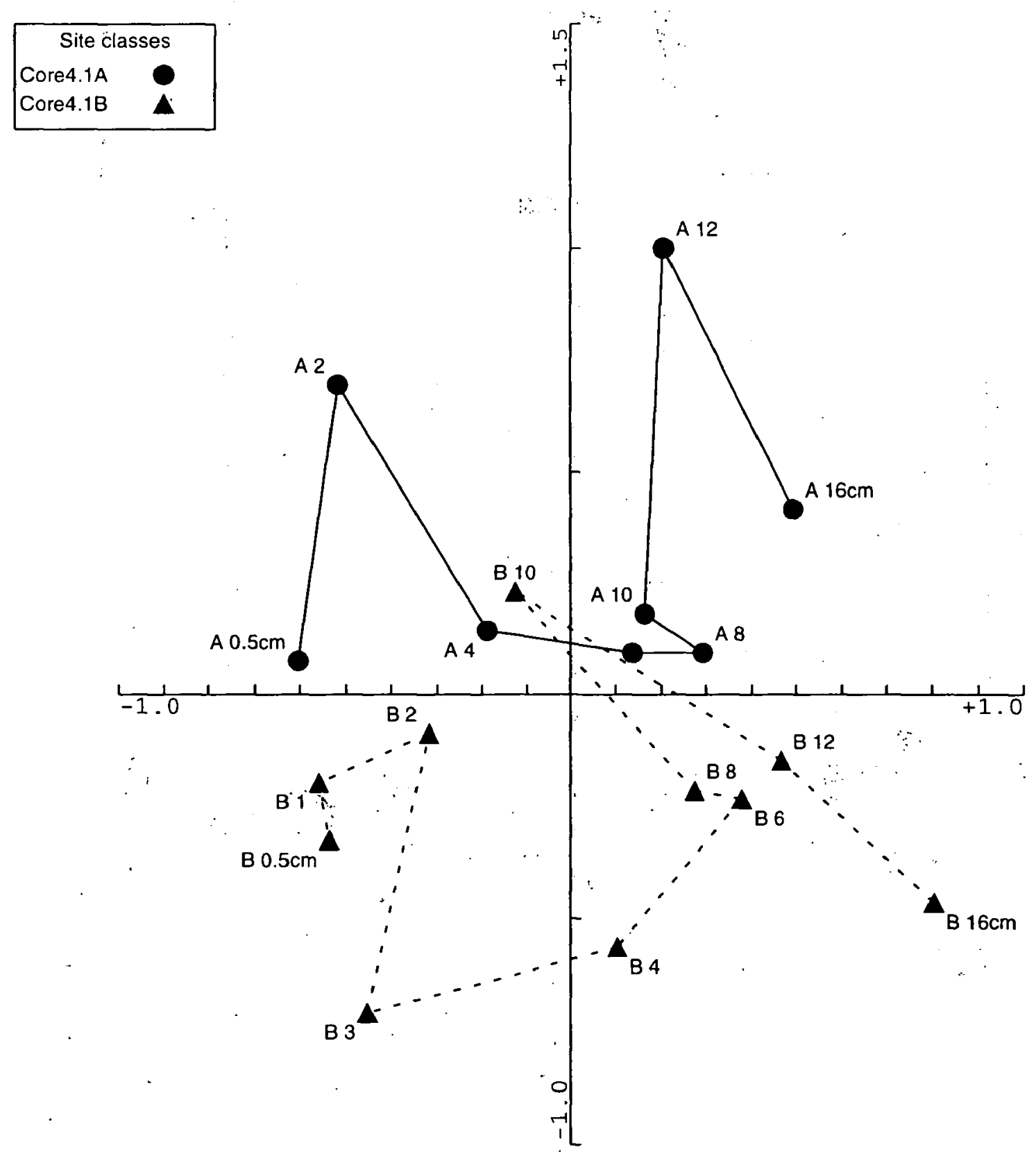

Fig.4. Principal component ordination of samples in core 4.1A and core 4.1B from relative abundance of chironomid species data.

Fig. 4. Analyse en Composantes Principales des échantillons des carottes 4.1 A et 4.1 B à partir de l'abondance relative des espèces de Chironomidés. 
A and B. Based on this pattern, we suggest that the first axis reflects the main gradient of a directed environmental change experienced by the chironomid communities of Store Hovvatn from ca. 1730 to the mid 1970s.

\subsection{Chemical stratigraphy and community change}

Ordination of the species data with PCA (Fig.4) indicated a gradient in the development of the community up-core. In order to explore this pattern of change in more detail we analysed the species data with a set of environmental data elaborated from previous studies of core 4.1A (Norton \& Hess 1980, Davis et al. 1985). Because of the apparent incompatibility between some levels in the A- and B-cores we were reluctant to associate chemostratigraphical data from the A-core with specific depth levels in the B-core. Thus, these analyses were based exclusively on data from core 4.1 A. The environmental variables initially included in the analysis were accumulation rate of head capsules, TOC, $\mathrm{pH}$ (Davis et al. 1985), sediment organic matter, lead $(\mathrm{Pb})$, zinc $(\mathrm{Zn})$, and aluminium $(\mathrm{Al})$. Coarse profiles for these variables are shown in Fig.5. Profiles with better resolution are found in Norton \& Hess (1980).

An initial explorative run with all seven variables in a detrended correspondence analysis (DCA) returned ordination axes longer than four standard deviation units, which suggests that a unimodal response model for the species data would be more appropriate than a linear model (ter Braak 1987-92). However, the relationship between numbers of species, numbers of sites and numbers of environmental variables in the data do not fulfill the requirements necessary for application of canonical correspondence analysis (i.e. a unimodal model). Accordingly, we used redundance analysis (RDA) (i.e. a linear model) in the direct analysis of the relationship between the species data and the selected environmental data from the core.

The results from executing RDA with all variables showed that (inferred) TOC and $\mathrm{pH}$ were strongly correlated and that sediment organic matter was strongly correlated with sediment lead concentration (Table 3 ): The intercorrelated variables also returned high variance inflation values (see ter Braak 1987-92) and their independent statistical effects could not be singled out. The procedure with forward selection of the variables suggested that $\mathrm{pH}$, sediment organic content, zinc and aluminium provided the best explanation for the variance in the species data. In order to reduce the number of variables in the analysis we excluded TOC, $\mathrm{Pb}$ and head capsule accumulation rate. Results of RDA with this reduced set of variables are summari- zed in Table 4 ( $p<0.02$, Monte Carlo overall test for significance) and in Figs.6-7. Axis 1 explains $36.7 \%$ of the variance explainable by the species data $(p<$ 0.03 ). The interset correlations of environmental variables with the ordination axes (Table 5) show that $\mathrm{pH}$ $(r=-0.895)$ and $\mathrm{Al}(\mathrm{r}=-0.869)$ are highly correlated with axis 1 , while organic content $(r=-0.790)$ and $\mathrm{Zn}$ $(r=-0.554)$ are more strongly correlated with axis 2 .

In order to test hypotheses arising from these results we executed a series of partial, constrained RDAs with Monte Carlo permutations.

The results from this analysis (Table 6) indicated that significant parts of the variation in the species data can be explained with reference to either inferred $\mathrm{pH}$ $(p<0.01)$, sediment organic content $(p<0.04)$, or sediment aluminium content $(\mathrm{p}<0.01)$ alone.

\subsection{Species responses to environmental change in Store Hovvatn}

The results from RDA indicated that about $1 / 3$ of the species in the core had a variance that could be explained $80 \%$ or more by the first four axes (Table 7). Recalling that axis 1 might be interpreted as a $\mathrm{pH}$ or aluminium gradient (Table 5), very few individual species could actually be pinpointed as either particularly $\mathrm{pH}$ sensitive or tolerant on the basis of these results. However, $74 \%$ of the fit for $M$. pedellus and P. pullum is associated with the first axis (Table 7), indicating sensitivity to low pH (Fig.7) or to some other factor associated with low $\mathrm{pH}$ values. Species like $H$. marcidus and $D$. modestus appear to be more robust to low $\mathrm{pH}$ values (Fig.7).

\subsection{The chironomids of Store Hovvatn 1977-78 and Lille Hovvatn 1988-92}

Both these lakes can be considered chronically acidified. Thus the benthic macrofauna is composed of species that are tolerant to low $\mathrm{pH}$ values. Table 8 gives the relative abundance of taxa calculated from two or more sampling dates. The samples of interest from Store Hovvatn are those from 5 and $10 \mathrm{~m}$ depth. Fourteen taxa were found at $5 \mathrm{~m}$ depth, Demicryptochironomus vulneratus, $H$. marcidus, and Procladius spp. were most abundant. At $10 \mathrm{~m}$ depth seven taxa were found, with Procladius spp. dominating. When the recent fauna of 1977-78 is compared with the findings of head capsules at the $0-1 \mathrm{~cm}$ sediment level, it is interesting to note that some taxa, including $D$. vulneratus, $P$. pullum are missing in the core samples.

In Lille Hovvatn, 15 taxa were found at $5 \mathrm{~m}$ depth, with $H$. apicalis, $H$. brundini, Tanytarsus spp., H. marcidus, and $M$. thienemanni dominating. At $10 \mathrm{~m}$ depth 


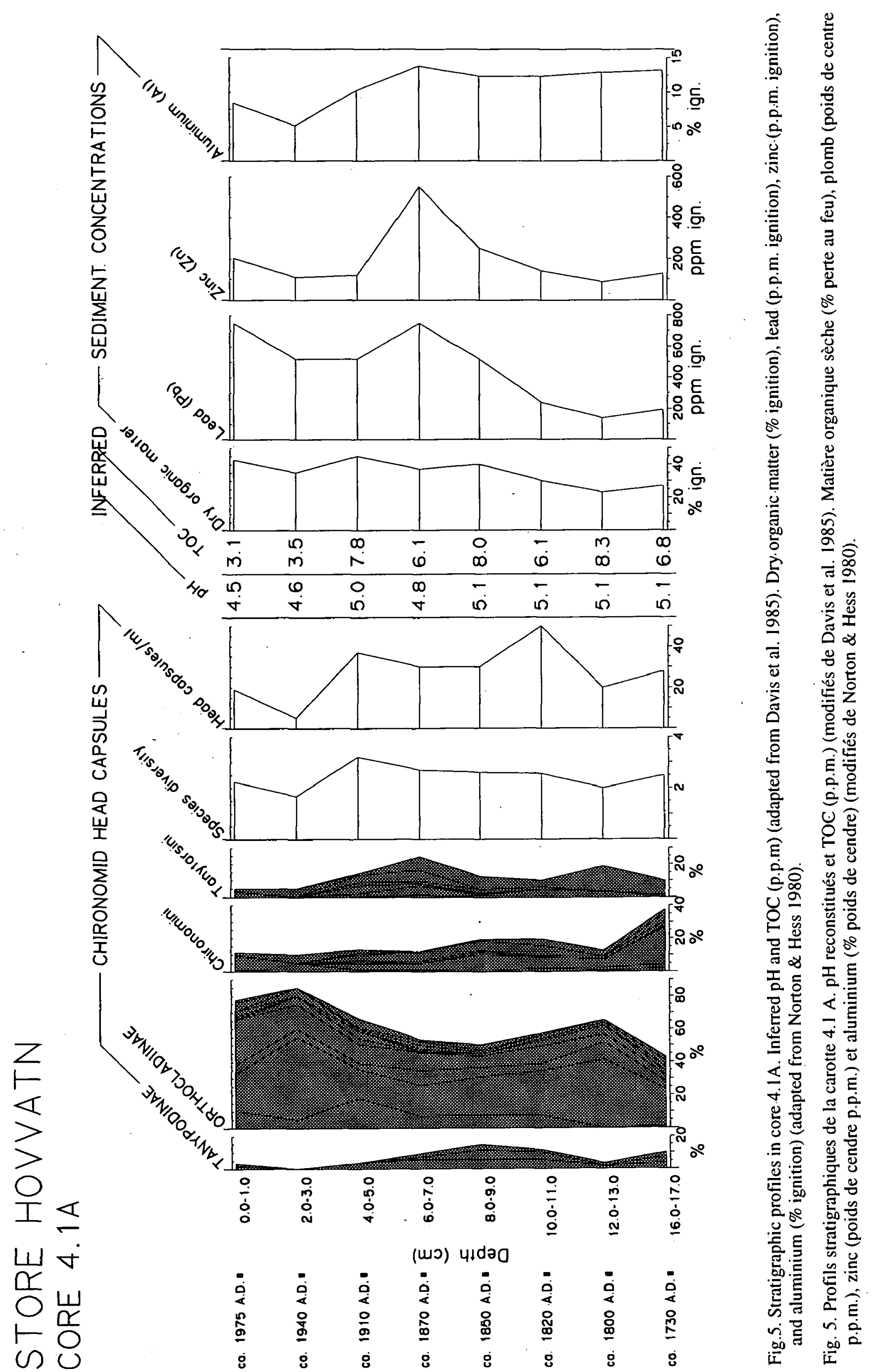


Tảble 3. Corrélation matrix of environmental wariables analysed from core 4.1A. TOC and pH reconstructed from diatoms (Davis et al. 1985), Organic= sẹdiment organic content, $\mathrm{Al}=$ ssediment aluminium content, $\mathrm{Zn}=$ sediment zinc content (from Norton \& Hess 1980), ac_rate= accumulation rate of chironomid head capsules.

Tableau 3. Matrice des corrélations des variables du milieu analysées dans la carotte 4.1 A. TOC et pH reconstitués à partir des diatomées (Davis et al. 1985): : teneurs du sédiment en matière organique (organic), aluminium (Al) et zinc ( $\mathrm{Zn}$ ) (d'après Norton \& Hess 1980); ac_rate $=$ taux d'accumulation des capsules céphaliques de Chironomidés.

\begin{tabular}{|c|c|c|c|c|c|c|c|}
\hline TOC & 1.000 & & & & & & \\
\hline $\mathrm{ppH}$ & 0.902 & 1.000 & & & & & \\
\hline organic & -0.354 & -0.547 & 1.000 & & & & \\
\hline ac_rate & 0.516 & 0.658 & -0.110 & 1.000 & & & \\
\hline $\mathrm{Pb}$ & 0.489 & -0.675 & 0.924 & -0.202 & 1.000 & & \\
\hline $\mathrm{Zn}$ & -0.048 & -0.209 & 0.501 & 0.307 & 0.690 & 1.000 & \\
\hline $\mathrm{Al}$ & 0.727 & 0.750 & -0.424 & 0.791 & -0.411 & 0.316 & 1.000 \\
\hline & TOC & $\mathrm{pH}$ & organic & ac_rate & $\mathrm{Pb}$ & $\mathrm{Zn}$ & $\mathrm{Al}$ \\
\hline
\end{tabular}

Table 4. Summary of RDA with chironomid relative abundances and chemostratigraphical data as environmental variables ( $\mathrm{pH}$ reconstructed from diatoms (Davis et al. 1985); sediment organic content, sediment zinc and sediment aluminium content scored from Norton \& Hess 1980).

Tableau 4. Récapitulation de l'analyse de redondance des abondances relatives des Chironomidés et des données chimiostratigraphiques comme variables du milieu (pH reconstitués à partir des diatomées (Davis et al. 1985) ; teneurs du sédiment en matière organique, zinc et aluminium évaluées d'après Norton \& Hess 1980).

\begin{tabular}{|c|c|c|c|c|c|c|}
\hline Axes & & 1 & 2 & 3 & 4 & Total variance \\
\hline Eigenvalues & : & 0.367 & 0.236 & 0.090 & 0.061 & 1.000 \\
\hline Species-environment correlations & : & 0.989 & 0.967 & 0.968 & 0.915 & \\
\hline \multicolumn{7}{|l|}{ Cumulative percentage variance } \\
\hline of species data & : & 36.7 & 60.3 & 69.3 & 75.5 & \\
\hline of species-environment relation & : & 48.6 & 79.9 & 91.9 & 100.0 & \\
\hline Sum of all unconstrained eigenvalues & : & & & $\cdot$ & & 1.000 \\
\hline Sum of all canonical eigenvalues & : & & & & & 0.755 \\
\hline
\end{tabular}

Table 5. Interset correlations (x100) of environmental variables with four axes resulting from RDA with chironomid and chemostratigraphic data ( $\mathrm{pH}$ reconstructed from diatoms (Davis et al. 1985); sediment organic content, sediment zinc and sediment aluminium content adapted from Norton \& Hess 1980).

Tableau 5. Corrélation entre les variables du milieu et les 4 axes résultats de l'analyse de redondance - Chironomidés et données chimiostratigraphiques - (pH reconstitués à partir des diatomées (Davis et al. 1985); teneurs du sédiment en matière organique, zinc et aluminium évaluées d'après Norton \& Hess 1980).

Variable

\begin{tabular}{|c|c|c|c|c|c|c|c|c|c|c|c|}
\hline $\mathrm{AX} 1$ & $\mathrm{AX} 2$ & $\mathrm{AX} 3$ & $\mathrm{AX} 4$ & $\begin{array}{c}\text { Fractior } \\
\text { Extracte } \\
0.48\end{array}$ & & $\begin{array}{c}\text { Fractior } \\
\text { Extracte } \\
0.24\end{array}$ & & $\begin{array}{c}\text { Fractiol } \\
\text { Extracte } \\
0.13\end{array}$ & & $\begin{array}{c}\text { Fraction } \\
\text { Extracte } \\
0.09\end{array}$ & \\
\hline-895 & 77 & -315 & -241 & organic & 511 & $\mathrm{pH}$ & 77 & $\mathrm{Zn}$ & 520 & Zn & 542 \\
\hline 511 & -790 & -237 & 72 & $\mathrm{Zn}$ & -177 & $\mathrm{Al}$ & -202 & $\mathrm{Al}$ & 322 & organic & 72 \\
\hline-177 & -554 & 520 & 542 & $\mathrm{pH}$ & -895 & $\mathrm{Zn}$ & -554 & organic & -237 & $\mathrm{Al}$ & -136 \\
\hline-869 & -237 & 297 & -219 & $\mathrm{Al}$ & -898 & organic & -790 & $\mathrm{pH}$ & -315 & $\mathrm{pH}$ & -241 \\
\hline
\end{tabular}


Table 6. Results of partial, constrained RDA with Monte Carlo permutation tests for significance (p) of axis l. Chironomid head capsules and chemostratigraphical data from core $4.1 \mathrm{~A}$. $\mathrm{pH}$ inferred from diatoms, Org=sediment organic content, $\mathrm{Al}=$ sediment aluminium content, $\mathrm{Zn}=$ sediment zinc content, $\alpha 1$ and $\alpha 2$ =eigenvalues of the first and second axis. Significant test results marked with an asterix.

Tableau 6. Test de signification (p) de l'axe I de l'analyse de redondance par la méthode Monte Carlo. Capsules céphaliques de Chironomidés et données chimiostratigraphiques de la carotte $4.1 \mathrm{~A}$. $\mathrm{pH}$ reconstitués à partir des diatomées. Teneurs du sédiment en matière organique (Org), aluminium ( $\mathrm{Al})$, ziṇc $(\mathrm{Zn}) ; \alpha 1$ et $\alpha 2=$ valeurs propres des axes 1 et 2 . Résultats des tests significatifs marqués d'un astérisque.

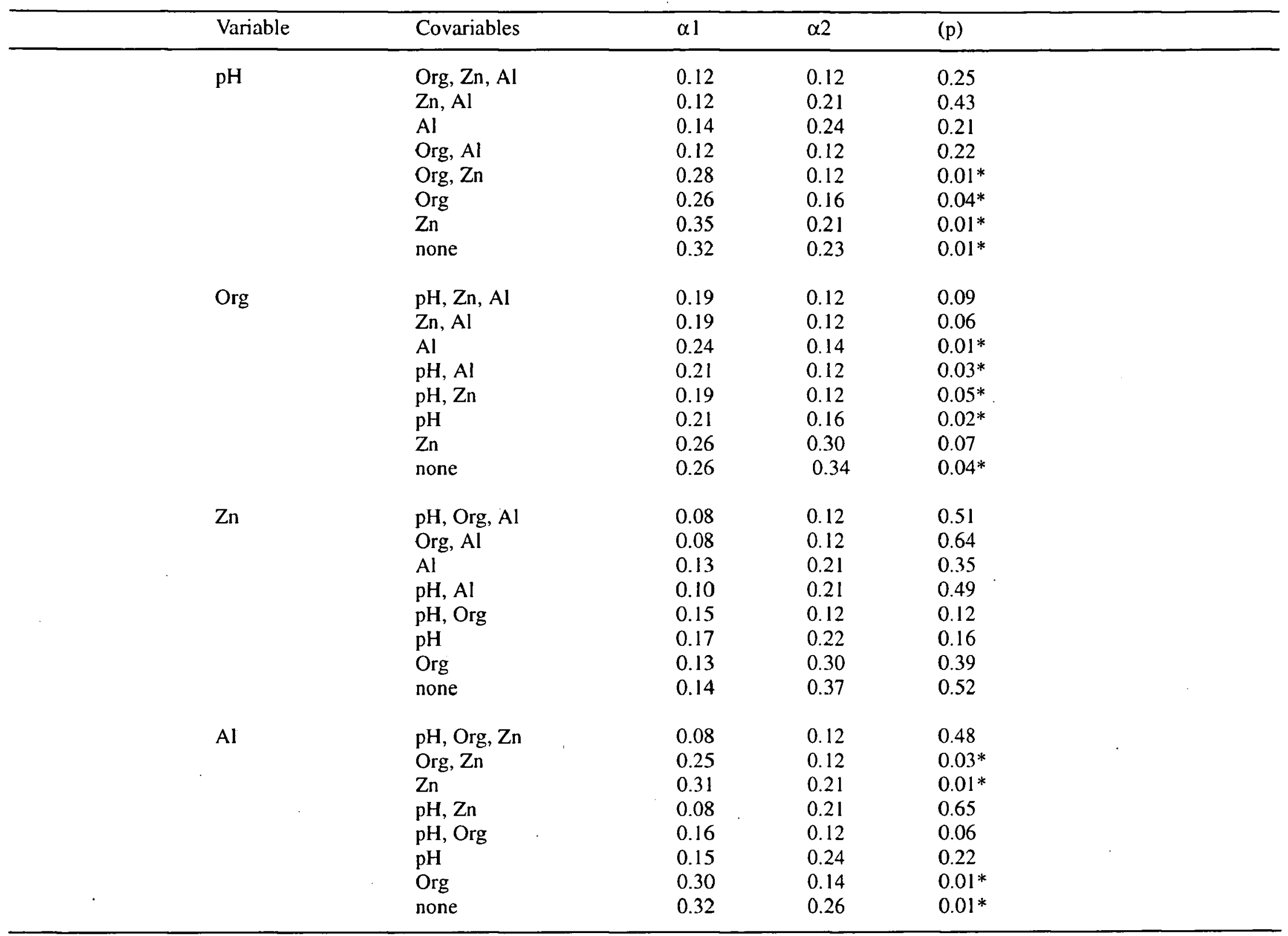

Table 7. Results from RDA with chironomid relative abundances and with chemostratigraphical data as environmental variables. Columns show cumulative fit of selected species as fraction of variance on first two axes, and total \% of variance explained (=expl.) by four axes.

Tableau 7. Résultats d'analyse de redondance des abondances relatives de Chironomidés et des données chimiostratigraphiques. Les colonnes montrent l'ajustement cumulatif de certaines espèces comme fraction de la variance des deux premiers axes et le \% total. de variance exprimé (=expl.) par les 4 axes.

\begin{tabular}{llcl}
\hline Taxon & Axis1 & Axis2 & expl. \\
\hline Ablabesmyia spp & 0.52 & 0.90 & 92.4 \\
Pentaneurini & 0.77 & 0.77 & 84.0 \\
Heterotanytarsus apicalis & 0.14 & 0.74 & 86.3 \\
Heterotrissocladius brundini & 0.07 & 0.80 & 88.4 \\
Heterotrissocladius marcidus & 0.76 & 0.84 & 86.3 \\
Psectrocladius calcaratus & 0.44 & 0.62 & 86.8 \\
Psectrocladius limbatellus gr & 0.07 & 0.41 & 88.4 \\
Tanytarsus signatus & 0.00 & 0.68 & 79.6 \\
Dicrotentipes modestus & 0.64 & 0.68 & 87.8 \\
Microtendipes pedellus & 0.74 & 0.74 & 79.9 \\
Polypedilum pullum & 0.74 & 0.79 & 90.2 \\
Chironomus cf anthracinus & 0.06 & 0.63 & 95.7 \\
\hline
\end{tabular}


Table 8. Relative abundance (\%) of taxa in composite benthic samples from Store Hovvatn 1977-78 and from Lille Hovvatn 1988-92.

Tableau 8. Abondance relative (\%) des taxa de l'ensemble des échantillons benthiques de Store Hovvatn 1977-78 et Lille Hovvatn 1988-92::;

\begin{tabular}{|c|c|c|c|c|c|c|c|}
\hline & \multirow[t]{2}{*}{ Taxon } & \multicolumn{2}{|c|}{$\begin{array}{c}\text { Store } \\
\text { Hovvatn }\end{array}$} & \multicolumn{3}{|c|}{$\begin{array}{c}\text { Lille } \\
\text { Hovvatn }\end{array}$} & \\
\hline & & $5 \mathrm{~m}$ & $10 \mathrm{~m}$ & $5 \mathrm{~m}$ & $10 \mathrm{~m}$ & $20 \mathrm{~m}$ & \\
\hline & Ablabesmyia monilis & 1 & 7 & 3 & 0 & 1 & \\
\hline & Ablabesmyia phatta & 2 & 0 & 0 & 0 & 0 & \\
\hline & Cladopelma viridula & 2 & 0 & 0 & 0 & 0 & \\
\hline & Demicryptochironomus vulneratus & 24 & 0 & 0 & 0 & 0 & \\
\hline & Dicrotendipes modestus & 5 & 0 & 2 & 0 & 1 & \\
\hline & Heterotanytarsus apicalis & 1 & 0 & 20 & 38 & 11 & \\
\hline & Heteromissocladius brundini & 0 & 0 & 19 & 10 & 3 & \\
\hline & Heterotrissocladius marcidus & 22 & 7 & 9 & 7 & 5 & \\
\hline & Macropelopia adaucta & 2 & 0 & 4 & 2 & 4 & \\
\hline & Mesocricotopus thienemanni & 0 & 0 & 7 & 13 & 3 & \\
\hline & Pagastiella orophila & 9 & 5 & 2 & 0 & 0 & \\
\hline & Parakiefferiella bathophila & 1 & 0 & 0 & 0 & 0 & \\
\hline & Polypedilum pullum & 11 & 3 & 0 & 0 & 0 & \\
\hline & Procladius spp. & 14 & 63 & 1 & 4 & 8 & \\
\hline & Protanypus spp. & 0 & 0 & 1 & 2 & 5 & \\
\hline & Psectrocladius limbatellus-gr. & 0 & 0 & 1 & 2 & 12 & \\
\hline & Psectrocladius psilopterus & 5 & 0 & 0 & 0 & 0 & \\
\hline & Psectrocladius septentrionalis & 0 & 5 & 0 & 0 & 0 & \\
\hline & Sergentia coracina & 0 & 10 & 4 & 19 & 47 & \\
\hline & Tanytarsus buchonius & 1 & 0 & 0 & 0 & 0 & \\
\hline & Tanytarsus signatus & 0 & 0 & 6 & 0 & 0 & \\
\hline & Tanytarsus spp. indet & 0 & 0 & 17 & 1 & 1 & \\
\hline- & Zalutschia zalutschicola & 0 & 0 & 5 & 1 & 0 & \\
\hline
\end{tabular}

13 taxa were found, H. apicalis, S. coracina, M. thienemanni and $H$. brundini dominated. At $20 \mathrm{~m}$ depth 12 taxa were found with $S$. coracina as the dominant species.

\section{Discussion}

\subsection{Community change in Store Hovvatn}

The assemblages of chironomid remains from Store Hovvatn show a fluctuating variation in species composition up-core (Figs.2-3). The data from core 4.1B may be seen as indicating somewhat stronger fluctuations in species composition than those of core $4.1 \mathrm{~A}$ (Fig.4). It is possible that the samples from core 4.1B reflect better resolution of oscillating environmental change since they were taken from $0.5 \mathrm{~cm}$ slices throughout the core, whereas the samples from 4.1A represent averages of deposited head capsules within 1 $\mathrm{cm}$ sections. The original chemostratigraphical profiles from core 4.1A (Norton \& Hess 1980) sometimes show dramatic change between $0.5 \mathrm{~cm}$ sediment levels and we would expect quick response to these changes in the species composition. Besides, the taxonomical resolution of core 4.1B is better. However, the samples from this core are also numerically poorer. This may contribute to lower precision in the estimates of relati- ve abundance and introduce error in the observed pattern of change.

Despite the irregularities between some pairs of samples from similar depth levels in the two cores, the species data from both cores point in the same general direction of community change (Fig. 4). Our analysis with RDA shows that a considerable proportion of this change might be explained as an effect of acidification as measured by $\mathrm{pH}$. If we maintain a sceptical attitude to the $\mathrm{pH}$ values used in the analysis (because they were not measured directly), sediment aluminium content is an alternative variable with significant explanatory potential, thus still indicating that acidification has been an important driving force, particularly in the later phases of biotic change in Store Hovvatn.

Although significant effects on growth and development of chironomids has been found with exposure to relatively low concentration of zinc (Timmermans et al. 1992 a,b), a community response to zinc content in the sediments is not clearly indicated from our analysis (Table 6). Other metals, like lead, and additional components that were not included in the analysis show similar stratigraphical profiles in the core and the complex questions of bioavailability (Luoma 1989) adds to the difficulties of interpreting specific direct effects 
from specific components in the changing water chemistry of Store Hovvatn.

Sediment concentration of trace metals like lead and zinc are, however, good indicators of acidic deposition and testify to rates in atmospheric emission of acidifying components (Rippey 1990). As previously shown by other authors (Norton \& Hess 1980) the sediment profile of lead in Store Hovvatn (Fig.5) indicates that atmospheric contamination may have started :already by the middle of the last icentury. Maximum lead concentration was found at $5.5 \mathrm{~cm}$ in core $4.1 \mathrm{~A}$ (Norton \& Hess 1980). A slight improvement in contamination input rates during the interwar years has been found in other Nordic lake profiles and has been thought to reflect a temporary stagnation of fuel consumption during years with an unstable 'World economy ((Bernes 1993).

The contamination of Store Hovvatn has previously been shown to affect the biological life in the lake. The cladoceran assemblages from core 4.1 A (Brakke 1980) decreased in numbers of species from $16 \mathrm{~cm}$ and towards the top as compared to the sections between 32 and $16 \mathrm{~cm}$. A decreasing number of individuals from 9 $\mathrm{cm}$ to the surface was also observed, and it was concluded that this was an effect of the acidification process.

Davis \& Berge (1980) studied the diatom communities in core 4.1A. They found two important shifts in the community composition, one at $8.5 \mathrm{~cm}$ and the other at $3.75 \mathrm{~cm}$ depth. The shift at $8.5 \mathrm{~cm}$ was seen by an increase in acidophilous taxa (mainly below $\mathrm{pH} 7$ ) over indifferent ones, while the shift at $3.75 \mathrm{~cm}$ was marked by a replacement of acidophilous by acidobiontic (optimum below pH 5.5) taxa. The latter episode was seen as indicating that acidification had become more extreme.

It is interesting to note that these two episodes correspond roughly to the transitions between our zones HA2/HA3 and HA3/HA4 respectively (Fig.2). However, although environmental change is indicated by the chironomids (Fig.2) from $8-9 \mathrm{~cm}$ to $6-7 \mathrm{~cm}$, for instance by the proportional relationship between Tanytarsini and Chironomini (Fig.5), this is not well reflected in the RDA ordination (Fig.6) and the number of species as well as the head capsule concentration are virtually unchanged through this interval of core 4.1A. In core $4.1 \mathrm{~B}$, the species diversity has a maximum at $8-8.5 \mathrm{~cm}$, but with the lack of dating it is difficult to assess that this level corresponds to the same level in core 4.1A.

The segments from 4 to $2 \mathrm{~cm}$ in core $4.1 \mathrm{~A}$ (Fig.2) and from 4 to $3 \mathrm{~cm}$ in core $4.1 \mathrm{~B}$ (Table 2) are characterized by a distinct decline in head capsule abundance and in the numbers of chironomid species. These ob- servations certainly refilect the most important ecological events in the modern history of Store Hovvatn and are probably causally linked ito:a permanent shift to extreme $\mathrm{pH}$ values. The concurrent drop in aluminium concentration (Fig.5) in the (core suggests that sediment trapping of this metal declined and that labile aluminium increased to toxic levels, at least for the trout population, which apparently went extinct during this period. The accumulation rate of head capsules is also strongly correlated with sediment aluminium content ('Table 3), and our RDA analysis suggests that the changing chironomid community in this segment of the icore might be conceived in terms of aluminium toxicity. These events were also associated with an inferred drop in TOC values from about 7 p.p.m to about 3 p.p.m. ((Davis et al. 1985), which must have affected a number of important ecological variables such as water colouration, light penetration and bathymetric distribution of $\bullet$ rganisms.

Those species with the most conspicuous dominance up-core (H. brundini, H. marcidus, $H$. apicalis, and $D$. modestus) are all commonly found in acidified lakes (Mossberg \& Nyberg 1976, 1979, Mossberg 1979, Raddum \& Saether 1981) and $H$. brundini is presently among the dominant chironomids in Lille Hovvatn. $H$. marcidus and $H$. apicalis are both important in the littoral and sublittoral zones of Store Hovvatn. In Lille Hovvatn all three species are among the dominant chironomids at 5, 10 and $20 \mathrm{~m}$ depth. From the concepts of classical lake typology (Thienemann 1941, 1954 ; Brundin 1949, 1956) the increasing relative abundance of orthoclad species up-core (Tables 1-2, Fig.5) indicates increasing oligotrophy and reduced production. The gradual increase in sediment lead content is closely correlated (Table 3, Fig.5) with an increase in sediment organic matter, indicating a long term retardation in decomposition and nutritient cycling that followed the increasing input load of acidifying components (Grahn et al. 1974).

\subsection{Species responses to acidification}

Although our results suggest that acidification might have been an important driving force in the gradual change of the species composition, there are few cues to suggest that those species with declining abundances up-core responded to physiological $\mathrm{pH}$ stress per se. Several of the species that can be associated with less extreme $\mathrm{pH}$ values (Fig.7) from declining relative abundances in core 4.1 A (Fig.2), for instance S.coracina, Ablabesmyia, $P$. calcaratus, and $P$. pullum were actually found under acid conditions, either in the top levels of core 4.1B (Fig.3) or in recent samples from the Hovvatn lakes (Table 8). 


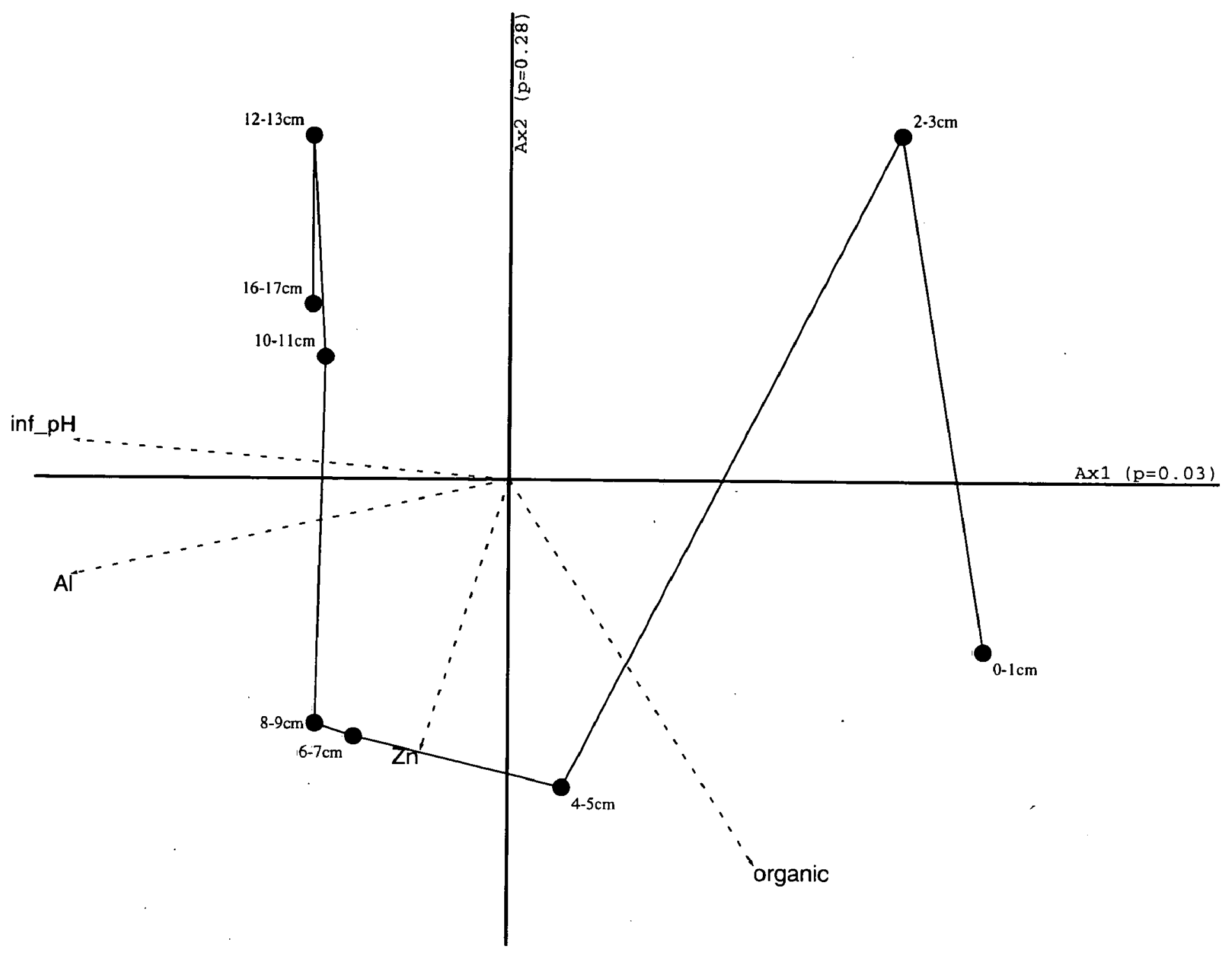

Fig.6. Biplot of core samples and environmental variables based on redundancy analysis (RDA) of data from core 4.1A. See Tables4-5 and text for explanation.

Fig. 6. Graphique des échantillons de carottes et des varïables du milieu d'après l'analyse de redondance des données de la carotte 4.1 A. Pour explication voir Tableaux 4-5 et texte.

M. pedellus is the only species that consistentily seems to respond to acidification from our data (Table 7). After liming of Store Hovvatn it has been found occasionally at 0.5 and $2 \mathrm{~m}$ depth, and it has never been found in the acidified Lille Hovvatn ( $\varnothing$.A. Schnell, unpublished). However, Mossberg \& Nyberg (1976) found both $M$ cf pedellus (as Microtendipes chloris var lugubris) and $M$. brevitarsis to be abundant in the strongly acidified Lake Västra Skälsjön in Middle Sweden, which shows that the two most common members of the genus in Scandinavia can tolerate acidification. Also, Raddum \& Saether (1981) found $M i$ crotendipes sp. (most likely the same species as in Store Hovvatn) to be common in an acidified lake situated only about $75 \mathrm{~km}$ west of Store Hovvatn. Likewise,
Meriläinen \& Hynynen (1990) found Microtendipes spp. at $\mathrm{pH}$ as low as 4.4 in Finland. This indicates that some other factor than low pH must be invoked to explain the absence of the species in Store Hovvatn today.

Our data from the cores suggest that the lake has become increasingly oligotrophic during the last 200 years. Johnson and McNeill (1988) found that the lakes studied by them had become increasingly oligotrophic during the last 130 years, prior to any anthropogenic acidification. They concluded that the trends observed probably were «natural, climate-related changes that have occurred continually through postglacial times». Our analysis of the species communities and chemostratigraphical data from Hovvatn 


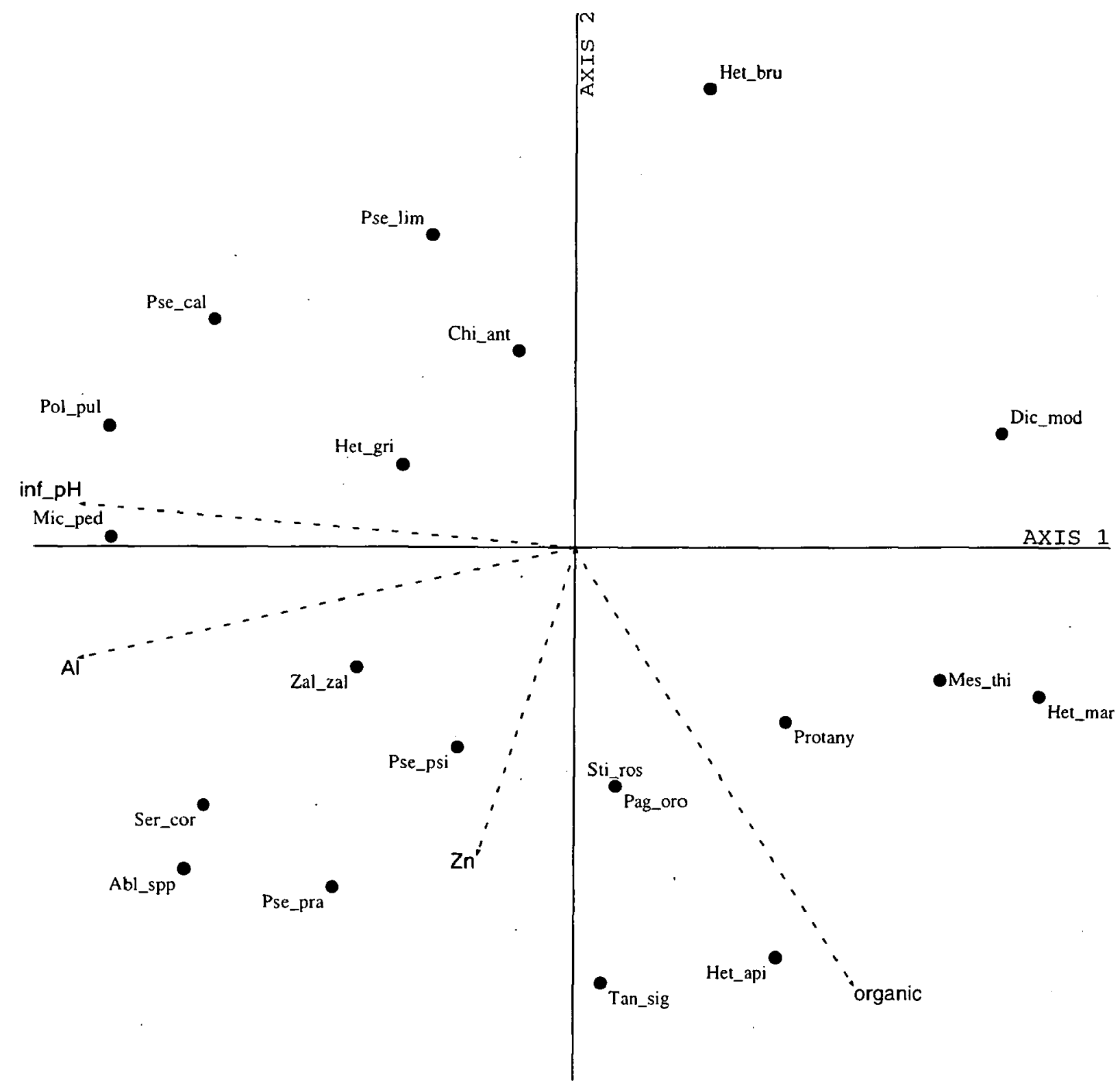

Fig. 7. Biplot of selected environmental variables and species based on redundancy analysis (RDA) of data from core 4.1A. See Tabs.4-5,7 and text for further explanation. Species are abbreviated with first three letters of generic and species name (see Fig.1).

Fig. 7. Graphique des variables de milieu et des espèces sélectionnées d'après l'analyse de redondance des données de la carotte 4.1 B. Pour plus d'explications voir Tableaux 4-5, 7 et texte. Abréviations des noms d'espèces avec les trois premières lettres du genre et de l'espèce (voir Fig. 1).

shows that a large part of the variation can be explained in terms of pollution impacts. This is particularly so for the events reflected in the levels from about 4 to $2 \mathrm{~cm}$ in the cores. However, because several of the variables that testify to pollution input and acidification are both intercorrelated and causally connected to productivity decrease, it may be difficult to single out underlying climatic variation. Although there is a clear trend in the development of the chironomid fauna, the oscillations of some species through the sequence are difficult to explain from these data.

\section{Acknowledgments}

We are grateful to professor Ronald B. Davis, University of Maine, for taking and storing the sediment cores. We also would like to thank Torunn Landås, Randi Lund and Mari Rajeswary Thavarajah for sorting out the head capsules from the sediments.

\section{References}

Anonymous 1987. - 1000 Lake Survey 1986 Nonway. National environmental monitoring programme, report 283/37. The Norwegian State Pollution Control Authority, Oslo, Norway : $33 \mathrm{p}$.

Baalsrud K. (ed.) 1985. - The Norwegian Liming Project - Final report. Directorate of Nature Management, Trondheim, Norway : $147 \mathrm{p}$.

Barlaup B.T., Åtland Å., Raddum G.G. \& Kleiven E. 1989. Improved growth in stunted brown trout (Salmo trutta L.) after reliming of Lake Hovvatn, Southern Norway. Water, Air, and Soil Pollution 47 : 139-151.

Barlaup B.T., Åtland Å., \& Kleiven E. 1994. - Stocking of brown trout (Salmo trutta L.) cohorts after liming - effects on survival and growth during five years of reacidification. Water, Air, and Soil Pollution 72 : 317-330.

Bernes C. 1993. - The Nordic environment. - Present state, trends and threats. Nord 1993 (12), Nordic Council of Ministers, Copenhagen, Denmark : $122 \mathrm{p}$. 
Brakke D.F. 1980. - Atmospheric deposition in Norway during the last 300 years as recorded in SNSF lake sediments. III. Cladoceran community structure and stratigraphy. In : Ecological impact of acid precipitation. (D. Drabløs \& A. Tollan eds.). SNSF project report, Oslo - Ås, Norway, : 272-273.

Brodin Y.-W. 1990. - Midge fauna development in acidified lakes in northern Europe. Phil. Trans. R. Soc. Lond., B 327: 295-298.

Brundin L. 1949. - Chironomiden und andere Bodentiere der südschwedischen Urgebirgseen. Ein Beitrag zur Kenntnis der bodenfaunistischen Charakterzüge schwedischer oligotropher Seen. Rep. Inst. Freshwat. Res. Drottningholm, 30:1-914.

Brundin L. 1956. - Die bodenfaunistische Seetypenlehre und ihre Anwendbarkeit auf die Südhalbkugel. Rep. Inst. Freshwat. Res. Drottningholm, 37 : 186-235.

Davis R.B., Anderson D.S. \& Berge F. 1985. - Palaeolimnological evidence that lake acidification is accompanied by loss of organic material. Nature, $316: 436-438$.

Davis R.B. \& Berge F. 1980. - Atmospheric deposition in Norway during the last 300 years as recorded in SNSF lake sediments. II. Diatom stratigraphy and inferred $\mathrm{pH}$. In : Ecological impact of acid precipitation. (D. Drabløs \& A. Tollan eds.). SNSF project report, Oslo - Ås, Norway, : 270-271.

Drables D. \& Tollan A. (eds.) 1980. - Ecological impact of acid precipitation. SNSF project report. Oslo - Ås, Norway: $383 \mathrm{p}$.

Grahn O., Hultberg H. \& Landner L. 1974. - Oligotrophication - a selfaccelrating process in lakes subjected to excessive supply of acid substances. Ambio, $3: 93-94$.

Henrikson, L. \& Oscarson, H.G. 1985. - History of the acidified Lake Gårdsjön : The development of chironomids. Ecol. Bull., $37: 58-63$.

Hindar A. 1987. - Overvaiking av Store Hovvatn etter kalking $i$ 1981 og 1987. Kalking av surt vann $3 / 88$, DN/NIVA, Trondheim, Norway : $71 \mathrm{p}$ (in Norwegian).

Hofmann W. 1986. - Chironomid analysis. In : Handbook of Holocene Palaeoecology and Palaeohydrology. (B.E. Berglund ed.) Wiley, Chichester, England : 7.15-727.

Hultberg H. 1985. - Changes in fish populations and water chemistry in Lake Gårdsjön and neighbouring lakes during the last century. Ecol. Bull., 37 : 64-72.

Johnson M.G. \& McNeill O.C. 1988. - Fossil midge associations in relation to trophic and acidic state of the Turkey Lakes. Can. J. Fish. Aquat. Sci., 45 : 136-144.

Luoma S.N. 1989. - Can we determine the biological availability of sediment-bound trace elements ? Hydrobiologia, 176/177: 379-396.

Meriläinen J.J. \& Hynynen J. 1990: - Benthic invertebrates in relation to acidity in Finnish forest lakes. In : Acidification in Finland. (P. Kauppi, P. Anttilla \& K. Kenttämies eds.) Springer Verlag, Berlin, Germany : 1029-1049.

Mossberg P. 1979. - Bottenfaunaens sammansättning i sura oligotrofa sjöar. Inf. Sötvatt. Drottningholm, 11 : 1-39 (In Swedish, with English summary).

Mossberg P. \& Nyberg P. 1976. - Försurningseffekter på bottenfaunaen och fisk i Västra Skälsjön. Inf. Sötvatt. Drotmingholm, 9:1-23 (In Swedish, with English summary).
Mossberg P. \& Nyberg P. 1979. - Bottom fauna of small acid forest lakes. Rep. Inst. Freshwat. Res. Drottningholm, $58: 77-87$.

Norton S.A. \& Hess C.T. 1980. - Atmospheric deposition in Norway during the last 300 years as recorded in SNSF lake sediments. I. Sediment dating and chemical stratigraphy. In : Ecological impact of acid precipitation. (D. Drabløs \& A. Tollan eds.) SNSF project report, Oslo - As, Norway : 268-269.

Raddum G.G., Brettum P., Matzow D., Nilssen J.P., Skov A., Sveälv T. \& Wright R.F. 1986. - Liming the acid Lake Hovvatn, Norway : a whole-ecosystem study. Water, Air, and Soil Pollution, $31: 721-763$.

Raddum G.G. \& Saether O.A. 1981, - Chironomid communities in Norwegian lakes with different degrees of acidification. Verh. Internat. Verein. Limnol., 21 : 399-405.

Rippey B. 1990. - Sediment chemistry and atmospheric contamination. Phil. Trans. R. Soc. Lond., B 327 : 311-317.

Ter Braak C.J.F. 1987-1992. - CANOCO - a FORTRAN program for canonical community ordination. Microcomputer Power, Ithaca, New York, USA.

Thienemann A. 1941. - Lappländische Chironomiden und ihre Wohngewässer. (Ergebnisse von Untersuchungen im Abiskogebiet in Schwedisch-Lappland). Arch. Hydrobiol. Suppl., $17: 1-253$.

Thienemann A. 1954. - Chironomus. Leben, Verbreitung und wirtshaftliche Bedeutung der Chironomiden. Binnengewässer, 20 : $834 \mathrm{p}$.

Timmermans K.R., Peeters W. \& Tonkes M. 1992a. - Cadmium, zinc, lead and copper in Chironomus riparius (Meigen) larvae (Diptera : Chironomidae) : uptake and effects. Hydrobiologia, 241: 119-134.

Timmermans K.R., Spijkerman E., Tonkes M. \& Govers H. 1992b. - Cadmium and zinc uptake by two species of aquatic invertebrate predators from dietary and aqueous sources. Can. J. Fish. Aquat. Sci., 49 : 655-662.

Walker I.R. 1987. - Chironomidae (Diptera) in paleoecology Quat. Sci. Rev., 6 : 29-40.

Walker I.R. 1995. - Chironomids as historical indicators of environmental change. In : Chironomidae: biology and ecology of non-biting midges. (P.D. Armitage, P.S. Cranston, and L.C.V. Pinder eds.) Chapman \& Hall, London, pp. 405-422.

Walker I.R., Fernando C.H., \& Paterson C.G. 1985. - Associations of Chironomidae (Diptera) of shallow, acid, humic lakes and bog pools in Atlantic Canada, and a comparision with an earlier paleoecological investigation. Hydrobiologia, 120:11-22.

Warwick W.F. 1980. - Palaeolimnology of the Bay of Quinte, Lake Ontario : 2800 years of cultural influence. Can. Bull. Fish. Aquat. Sci., $206: 117$ p.

Wiederholm T. 1983. - Chironomidae of the Holarctic region. Keys and diagnoses. Part 1. Larvae. Ent. Scand. Suppl., 19:457 p.

Wiederholm T. \& Eriksson L. 1977. - Benthos of an acid lake. Oikos, $29: 261-267$.

Wright R.F. 1985. - Chemistry of Lake Store Hovvatn, Norway, following liming and reacidification. Can. J. Fish. Aquat. Sci., $42: 1103-1113$. 